\title{
OS EFEITOS DE SENTIDO DO DISCURSO DA GUERRA
}

Debora Thais de Souza Freitas Prestes (Universidade Nove de Julho)

Ricardo Carvalho da Costa (Universidade Nove de Julho)

Este trabalho tem por objetivo geral examinar o discurso "A canção do senhor da guerra" por meio das categorias: condições sócio-históricas de produção, interdiscurso, cena de enunciação e ethos discursivo. Já os objetivos específicos são: reconhecer o interdiscurso presente no corpus selecionado; verificar a cena de enunciação por meio de recortes, identificar o ethos discursivo do enunciador do discurso e depreender efeitos de verdade. Nesse sentido, nosso problema de pesquisa questiona: em que medida a cenografia desvela o ethos discursivo do enunciador e, por conseguinte, seu posicionamento? Para responder a esse questionamento, fundamentamo-nos na Análise do Discurso proposta por Maingueneau (2008). Os resultados mostraram que o discurso "A canção do senhor da guerra" apresenta um modo de dizer que revela um enunciador que alerta sobre as consequências da guerra, por meio de cenografias como recados e avisos irônicos para os co-enunciadores, jovens da época de 1985.

Palavras-chave: discurso; cenografia; ethos discursivo; guerra. 